\title{
Something old, new, borrowed, and blue: towards a bottom-up agenda of the Finnish-Russian relations
}

\author{
JUSSI LAINE
}

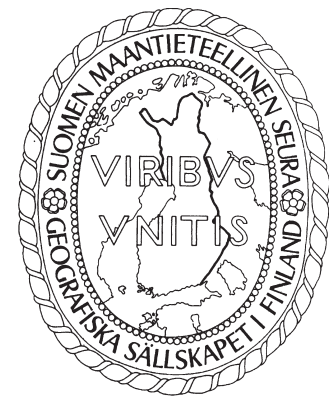

Laine, Jussi (2014). Something old, new, borrowed, and blue: towards a bottomup agenda of the Finnish-Russian relations. Fennia 192: 1, pp. 65-78. ISSN 1798-5617.

While the Finnish-Russian relations of today cannot be fully understood without understanding the past, it is equally important to know how to break away from it. When discussing cross-border interaction, one must be aware of the broader context within which these processes take place. The territorial sovereignty of the nation-state continues to form one of the leading principles upon which international relations are based, yet transnational relations are increasingly run by actors and organisations whose ability to function does not stop at the border. The Finnish-Russian border provides an illuminating laboratory in which to study border change. This article draws on the experience from this border where cross-border cooperation has reflected both the political and socio-cultural change as well as politically and economically motivated interaction. It argues that the best way to normalise neighbourly relations is through increased people-to-people interaction, and preferable this ought to occur from the bottom-up, not from the top-down. Civil society organisations themselves may need to take matters into their own hands and to seek further revenues through social entrepreneurship in order to ensure the continuity of cooperation. Much of the work is carried out heedless of individual project and programme frames. In practice, its success depends on individual actors who are able to shoulder the implementation of the agreed programs and to solve emerging problems and disagreements.

Keywords: Finland, Russia, European Union, border, civil society, interaction

Jussi Laine, Karelian Institute, University of Eastern Finland, P.O. Box 111 Fl80101 Joensuu, Finland, E-mail: jussi.laine@uef.fi

\section{Introduction}

On the face of it, the significance of Finland's borders appears unaffected. The border with Russia remains secure and well controlled; younger generations can hardly remember that there would have ever been a 'real' border with Sweden, and even fewer recall that Finland shares some $730 \mathrm{~km}$ of borderline with Norway somewhere up north. Running through nothing but forest and some occasional lakes for almost its entire length, the Finnish-Russian border does not inevitably appear to be a pressing research object, at first glance. In terms of dynamics, it fades in comparison with other European Union (EU) borders as well as with other seemingly asym- metrical borders, such as the border between the United States and Mexico.

Given what was stated above, the scholarly and popular attention the Finnish-Russian border has attracted, and continues to attract, is astonishing. Even though many of these writings discuss not the border per se but what lies beyond it, it is the border that has gained a sizable symbolic load. The lengthy shared border with Russia is still commonly put forth as excuse for why various issues are as they are and not necessarily as they could or should be. Everybody, even those who have never seen or crossed it, seem to know the meaning of it and what it stands for, and thus many statements on it go unquestioned. Alas, quantity does not compensate for quality. It has been customary to 
assume a rather (banal) nationalist stance and build on uncontroversial acceptance of the historical setting and current state of affairs. Their actual merits aside, such writings reproduce a particular image and perspective and in so doing diminish room for alternative views. While historical perspective and context specificity are crucial for understanding a particular border, the Finnish-Russian one in this case, placing it in the greater European perspective broadens the analytical frame and allows for the interpretations that a more narrow approach might preclude.

Similarly, the borders of a particular discipline, geography in this case, might also confine the analytical lens. Even if disciplinary specialisation has its benefits, a strict immersion in a particular field, as Strober (2006: 315) notes, may limit social innovation and the intellectual horizon of researchers. Interdisciplinary research, in turn, runs counter to the disciplinary taken-for-grantednesses, thus allowing more holistic, richer understanding of the topic at hand. As Baerwald (2010: 494-495) remarks, the drive to study the broad ranging and intertwined problems that encompass a complex mix of phenomena and processes, which taken together lie beyond the margins of existing disciplines, has impelled the conduct of research that necessitates inter-, if not postdisciplinary approach. Fortunately for geographers this is not a major cause for concern. While many traditional disciplines are defined by the topics that they study, geography has been inherently interdisciplinary since its establishment as a modern discipline.

This article draws from the experience from the border between Finland and the Russian Federation where cross-border cooperation (CBC) has reflected both the political and socio-cultural change as well as politically and economically motivated interaction. The border provides an illuminating laboratory in which to study border change - or the lack thereof. Finland's post-World War II relationship with the Soviet Union, and more recently with Russia, has been both close and distant - at times both concurrently. It has been shaped by a common history, Cold War realities, pragmatism, interdependencies and the lessons learned from devastating armed conflicts. Through the analysis of perspectives of civil society actors and those voiced in the media, this study strives to achieve a better understanding of present-day multi-layered Finnish-Russian relations, especially with respect to the role that civil society plays. The goal is furthermore to introduce new, more nuanced perspectives to the discussion on Europeanisation of the institutional and discursive practices of CBC. Empirically, this article draws from a mix of material and methods involving the mapping of actors, newspaper screening, basic background and more thorough in-depth interviews (96 in total) and document analysis. While the material at hand has been elaborated in detail elsewhere (see Laine 2013), this article focuses on analysing the development of the operational forms of cooperation at the Finnish-Russian border and suggesting a future trajectory based on the collected empirical material.

As O'Dowd (2010) argues, by privileging spatial analysis and over-emphasizing the novelty of ongoing forms of globalisation, many contemporary border studies lack an adequate historical analysis, arriving, thus, to a disfigured perspective of the present. After providing a brief overview of the border studies, this article seeks to recognise the past in the present by looking back to the distinctive history of the Finnish-Russian border and discussing the development of the cross-border relations in the prevailing contexts. It then proceeds to assess the current situation and places the binational setting in the broader European context, to which it is now inherently linked. The article concludes by providing suggestions for the future management of the cross-border relations.

\section{Border studies as a field of interest}

Borders have long been one of the most central topics to political geography. However, the focus of border studies has gone through substantial changes as it has developed in relation to the predominant geopolitical models and visions - from studying borders as delimiters of territorial control and ideology towards areal differentiation and later towards more dynamic role of borders as bridges rather than barriers.

The emergence of globalisation and the rhetoric of a 'borderless world' only fuelled interest in borders. The apparent renaissance of border studies that followed acquired an increasingly interdisciplinary take. The significance of borders is doubtlessly in flux, but instead of disappearing altogether, the borders themselves seem to be merely changing their institutional form. The traditional definitions and comprehensions of borders have been challenged primarily because the context in 
which they were created and existed has also altered.

Recently, geographers have delved, inter alia, into the interrogating potentials for a democratic governance of borders (Anderson et al. 2003), exclusion and discrimination (van Houtum \& Pijpers 2007; van Houtum \& Boedeltje 2009), the technologisation of borders and visualisation practices (Amoore 2009), violence of borders and 'teichopolitics' (Elden 2009; Rosière \& Jones 2012), the relationships between 'traditional' borders and the socalled borderless world of networked, topological space (Paasi 2009), external drivers, such as the EU and CBC (Popescu 2008; Johnson 2009), the conflicting logics of 'national' borders and 'supranational' unity (Sidaway 2001), and the 'new' European borders as 'sharp' markers of difference (Scott \& van Houtum 2009). However, geography by no means monopolises border studies. Borders have spread also not just into international relations, political sociology, and history, but also into cultural studies (Rovisco 2010) and philosophy (Balibar 2009). The bordering (border-making) perspective not only transcends disciplinary boundaries, but it takes a step further by advocating that scientific knowledge ought not to be privileged over everyday geographical imaginations and popular geopolitics (Scott 2009).

In the field of border studies, theorising has proven to be quite a challenge. All borders are unique, and each of them is related in different ways to local, regional, state-bound, and supranational processes - the geosociologies of political power (Agnew 2005: 47). As a result of this, however, concerns have been raised that during the past decade border studies have been overly focused on case study material, which has been thought to overshadow attempts to develop the discussion of concepts, theories, and common ideas (Newman 2012). There is little abstract theorising in border studies, and those who have attempted to theorise on borders have run into unique circumstances that make it impossible to conceptualise broad scale generalisations (Kolossov 2005; Newman 2006).

Even so, attempts have been made. Van Houtum and van Naerssen (2002) have sought to understand borders through sociological concepts of ordering and othering. Brunet-Jailly (2004, 2005) has put forth an attempt to theorise by drawing the general lessons that single case studies can offer. The same logic has been used more recently by Moré (2011). Newman, who earlier went against the grain by calling for a general border theory (Newman 2003a, 2003b, cf. Brunet-Jailly 2004, 2005; Kolossov 2005; Paasi 2005a, 2005b; Rumford 2006), finally gave up and accepted that "it is futile to seek a single explanatory framework for the study of borders" (Newman 2006: 145). Border as a research topic is complex, making the study of borders so diverse, both in terms of geographic and spatial scales, that any attempt to create a single analytical metatheory is doomed to failure.

Even if most scholars have given up on the enterprise, Payan (2013: 3) continues to insist that in order to advance the field of border studies beyond purely descriptive work, "[c]ontinued theorising on borders is not only a pending task but necessary today, particularly because the optimistic discourse on a borderless world... has fallen flat and there is in fact a renewed importance assigned to borders both in the political and in the policy world." He claims that the path to border theorising is not closed but only out of sight because border scholars have been looking in the wrong place. Precisely due to the fact that border scholars are spread around the world and are in fact disciplinary and geographical specialists, "often miss the forest for the trees, and need to take the bird's eye view and find what unites us" (Ibid.).

What unites us, Payan (2013) suggests, is our methods: in order to theorise on borders, scholars need to engage in a dialogue on the methodological strategies as well as the tools used and pick those that can enhance our explanatory power. Even though Payan is correct in arguing that more comparative work in teams is needed in order to discover the optimal tools to identify what actually gives shape and character to the borders of today, his argumentation postulates that border studies would form its own academic discipline, no different in nature, say, from geography, sociology, history, or anthropology with their own accustomed and well established currents of research. That, border studies is not.

This article puts fort that the main contribution of border studies lies in its ability to draw different disciplines together. It is fuelled by the diversity carved out by its eclectic multidisciplinarity. Creating a metatheory and naming the variables to be used by all would only restrict the potential that border studies has to offer. It is given that building theories and testing them in practice advances our knowledge. This must not however be done at the expense of context specificity. All the borders are unique and it is this uniqueness that makes border 
studies so interesting. While there is no need to create a single theory, we need not restrict ourselves to mere case studies either. We can go one step further to establish broader conceptualisations, trajectories, and even a common glossary in order to understand causality and to enhance the explanatory and predictive power of the methods used. While all borders are unique, they are still affected by the same global phenomena; it is their regional implications that differ.

Despite the forces of globalisation, we remain located somewhere and this has an impact on how we perceive that which surrounds us. Even if geographical realities do not change, their meaning for different purposes may. As a result, borders may lose some of their functions while simultaneously obtaining new ones; these functions are seldom stable but rather under continuous change. Borders may not disappear completely, but they can become more transparent and permeable in terms of some of their functions. A gradual opening of a previously closed national border enables the formation of new forms of interaction between countries but may also reveal political, cultural, and economic inequalities. All this makes them more tangible for people, especially borderlanddwellers.

This is exactly why we need to place people at the center of things: "[p]eople are not only at the center of world politics, but they 'make' politics" (Warkentin 2001: 14-15). People as agents, as actors and doers, have the ability to make things happen and, secondly, people are also social beings, naturally oriented towards establishing and maintaining social relations and conducting their lives within the context of relational networks (ibid. 17).

\section{Shifting significance of the Finnish- Russian border}

The significance of the Finnish-Russian border has been highly varied, reflecting not only FinnishRussian relations but also changes in global geopolitics (Paasi 1999: 669). The border was first drawn as a result of the Treaty of Nöteborg in 1323 between the then rulers of Sweden and Novgorod, but was then frequently redrawn according to the changing balance of power. In practice, however, the border did not exist at the regional level and people were free to move back and forth for centuries.
While Finland then became an autonomous grand duchy within the autocratic Russian Empire in 1809, it nevertheless maintained a national economy and a customs border with Russia. Even then, in other respects the border was an open one and very much a formality (Paasi 1996; Liikanen et al. 2007: 22). Be it as it may, for the first time in history, Finland formed an administrative unit of its own (Katajala 1999).

The border became progressively defined in terms of an autonomous nation-state in the course of the nineteenth century, when an active nationbuilding process gained ground in Finland (Liikanen 1995). Broad social and political mobilisation gained momentum at the beginning of the twentieth century depicting the border as a political, social, and cultural dividing line (Alapuro 1988). As Alapuro and Stenius (1989) suggest, such civic popular movements played a crucial role in providing the emerging nation with an intellectual or material maturity to declare independence in 1917, following the Bolshevik Revolution in Russia.

The Republic of Finland and Soviet Russia signed a peace treaty (Treaty of Tartu) in 1920 in order to stabilise political relations and settle the borderline between them. In Finland, a strong effort was made immediately to secure the border in order to signify the territoriality of an independent state. A heavily guarded, hostile military border was formed and all forms of cooperation interrupted.

The border between Finland and the Soviet Union was the longest border between a western capitalist state and a socialist super power (Paasi 1999: 670). In addition to its ideological weight, the border was increasingly perceived as playing distinct historical, political, natural, and yet artificial roles (Paasi 1996), the influences which are still felt today. Within the Cold War geopolitical order, Finland sought neutrality and became placed into the grey zone between the Eastern and Western blocs. Whereas Finland had been a 'Western' country in the geopolitical literature prior to World War II, many post-war representations placed it in Eastern Europe (Paasi 1996) as "a semiindependent oddity positioned under the Russian sphere of influence" (Moisio 2003).

The crux of the matter was that the 1948 Agreement of Friendship, Cooperation, and Mutual Assistance allowed the Soviet Union to interfere with Finland's domestic life. Even though the new geopolitical regime based on the treaty included more 
extensive economic interaction, the border remained heavily guarded and practically closed. The longer it remained closed, the wider the gap between the countries grew. This was hardly helped by the fact that during the Cold War the border became increasingly seen as a line divining two competing socio-political systems, the communist and the capitalist, and forming a 'civilisational' frontier zone between East and West.

The situation changed radically once the Soviet Union ceased to exist. Finland recognised the Russian Federation as the Soviet Union's successor and was quick to draft bilateral treaties with it. The new treaty, named straightforwardly as the "Agreement on the Foundations of Relations between the Republic of Finland and the Russian Federation" (Finnish Treaty Series 63/1992) and consisting of 12 compact articles, was signed with a newly formed Russia in January 1992. Its adaptation nullified the previous friendship treaty and the special relations dictated by it. The treaty also set in motion Finland's Neighbouring Area Cooperation (NAC) programme, which then became the key channel for cross-border interaction with Russia. Perhaps the most significant aspects of the new treaty was that it allowed Finland to make the move towards what was consider to be its right reference group (Sutela 2001: 6-7); in March 1992, only a few weeks after signing the new treaty, Finland applied for EU membership.

\section{The EUropean Frame}

When joining the Union in 1995, Finland jumped onto a moving train. The process of European integration was underway and had been fuelled remarkably, first, by the signing of the Single European Act in 1986 and, second, by the new enlargement prospects evoked by the collapse of the Soviet Union and the end of the Cold War. By its nature this process necessitated policies aiming to transcend internal borders, perceived in Schumanian integrative spirit as products and remainders of former conflicts. Borders were depicted as the results of the differentiation of groups in space. Keeping 'us' apart from 'them,' they were perceived to preserve heterogeneity and a lack of coherence, both to be replaced with unity and common Europeanness. As integration was assumed to follow from increased interaction, borders as barriers had to be eroded, whereby the role of borderlands as integrators became of high importance.
Underpinned by a strong regional development and spatial planning rationale, cross-border cooperation became a tool for building cohesion and blurring divides while local cross-border diplomacy enjoyed, first and foremost, a more a symbolic status.

With the EU membership, activities formerly administered through bilateral, state-level agreements became a part of the broader dynamics of international politics and EU-Russia relations. The binational border was suddenly upgraded to an external EU border, and this necessitated also amendments in political language and rhetoric. As Emerson (2001: 29) states, the Finnish-Russian border served as a prime example of a clean-cut periphery where one empire ended and another began. The Finnish domestic debate thus acquired an alternative thread, which depicted Finland, having the only EU land border with Russia, as a sort of a bridge builder between the two. For this reason and also because of the increased importance of the EU's borders that was observed in the key EU decision-making bodies, Finland now had a unique opportunity to profile itself in the field.

Given its geographic location, Finland became a logical avenue for increasing EU-Russian trade. The Finnish easterly business expertise stemming from the Soviet era was used to market Finland both as a gateway to Russia and a window to the West. As a new EU member state, Finland was also interested in providing the EU with a special agenda towards its Russian border, i.e., towards the "challenges and possibilities presented by having Russia as a neighbour" (Stubb 2009). This then materialised in the form of the Northern Dimension initiative.

The opportunities were not, however, really realised until it became clear that Finland's distinction of being Russia's only EU neighbour would be threatened by the upcoming 2004 enlargement. While the domestic debate remained largely unchanged, at the EU level Finland began, wilfully and consistently, to proclaim itself as something of a litigator of Russia in all things Europe, even if with only occasional success, claiming to possess Russian expertise that others did or could not have (Laine 2011). The Finnish-Swedish border became an internal EU border, yet practically nothing changed, as passage had been unrestrained already for decades. Thanks to the Nordic Passport Union, also the Finnish-Norwegian border, now officially an external EU border, remained uncon- 
trolled. As of 1996, all Nordic countries joined the Schengen Agreement, which became fully applied from March 25, 2001 onwards.

The 2004 enlargement of the EU and the introduction of European Neighbourhood Policy (ENP) policy epitomise a political attempt to extend the 'de-bordering' momentum of the late 1980s and 1990s beyond the territory of 'Core Europe' (see e.g. Scott 2009). The EU embarked on an ambitions mission to look beyond its internal borders and create a transnational space extending beyond its external borders by engaging neighbouring states in a new process of cross-border regionalisation. Despite being marketed as 'Ring of Friends,' this approach embodied an apparent shift whereby the 1989-2003 'scars of history' discourse that had attempted to transcend borders began to be replaced by a securitisation discourse. Particularly the external borders re-emerged in practical and discursive/symbolic terms as markers of sharp - to an extent civilisational - difference (van Houtum \& Pijpers 2007).

Suffering from an acute form of enlargement fatigue, the EU moved to stabilise and consolidate itself as a post-national political community. Formal relations with the neighbouring countries were privileged at the expense of local cooperation, which as a consequence became increasingly based on context and need ad hoc. This transformed the integrative role of the borderlands to that of a buffer zone or a filter. While the new forms of regional cooperation were presumably based on mutual interdependence, the EU's restrictive border and visa regimes gave an unambiguously exclusionary impact, making the EU seem to be a contradictory international actor.

Following the rise of nationalist populism, sparked by the events of 9/11 and fuelled further by threat scenarios of illegal immigration and a general loss of control over not just borders but domestic issues of all sorts, defining 'European' in cultural-civilisational terms became an increasingly mainstream political discourse. This led to a heightened demand for more defensive borders for the EU as a whole. On the level of member states, the reclamation of national identity and sovereignty, often termed as a 're-bordering' (Scott 2009; Dimitrovova 2012) led the national governments to challenge the EU's top-down supranational thrust. In Finland, the rise of national populism was not directed in any specific way against Russia or Russians but built on the argument that immigrants in general are threatening Finnish jobs and welfare and, in more extreme cases, Finnish culture. Similar tendencies are apparent in Russia, where its leadership has resorted actively to nationalist rhetoric and foreign threat scenarios in order to lead the lower and the upper classes and to control the growing middle class and civil society in between.

The consequent juggle between cooperation and security-oriented agendas has led to contradictory bordering practices whereby a considerable gap exists between the projected geopolitical vision and its translation into action. A telling indicator of this is the imbalance in resources allotted to CBC. While the EU's Cohesion and Regional Policy for 2007-2013 has an operating budget of EUR 347 billion $35.7 \%$ of the total EU budget for that period), the budget for the European Neighbourhood and Partnership Instrument (ENPI) for the same period amounts to some EUR 11 billion - only some five per cent of which is allocated for actual CBC programs. Ironically, this is less than what the EU is investing in security research under its wider R\&D budget for 2007-2013. Accordingly, the EU's promise of a 'privileged partnership' is downplayed by the fact that while the ENPI does provide limited co-funding also for non-EU members, the sums are much less than what was available through previous programs.

\section{Russia: so near and yet so far}

Today, the spectrum of Finnish-Russian relations is unprecedentedly broad and diverse. Still, at least the official storyline focuses mainly on interstate relations, fostering in so doing the perception of the Finnish-Russian border as a traditional binational state border, on the different sides of which Finnishness and Russianness, respectively, is acted out in the frame of a nation-state. Such a collective 'practice of nation' affects also political behaviour by relocating the emphasis of understanding away from powerful social actors to the everyday repetition of national 'rituals' (Githens-Mazer 2007).

Even though the dialogue between the two countries has become more 'normal,' at the level of interstate relations Finland has sought to continue the 'special relationship' and stay among the 'good countries'. The Presidents, the Prime Ministers, and Foreign Ministers meet regularly during bilateral visits but also at international and European forums. Within the Cabinet Finland's relationship with Russia is discussed on a regular ba- 
sis. In addition, the aim has been to create direct and effective relations between all ministries and key government bodies with their counterparts in Russia. According to Alexander Rumyantsev (2012), the current Russian ambassador to Finland, Finnish-Russian relations are built on mutually beneficial issues. According to him, these include open political dialogue, increasing trade, more than ten million border crossings, a gas pipeline in the Baltic Sea, the Saimaa Canal, the Helsinki-St. Petersburg high-speed railway, and cultural cooperation.

Even though Finnish-Russian relations are commonly addressed from a more or less equal footing - in the media and also in academia - it is hard to erase the apparent fact that the relationship is, in the end, quite a typical relationship between a small state and a superpower. Russia is not Sweden for Finland, nor should it be (Lounasmeri 2011: 15). Such neighbourly relations are always more important for the smaller country - Finland needs Russia, but Russia would quite likely manage just fine without Finland. The city of St. Petersburg alone has a greater population than Finland as a whole. By total area, Russia is 50 times larger than Finland, and the Soviet Union was 66 times larger.

The two countries share significant overlaps in history, and with the exception of a couple of conflicts, the relationship between the two has remained somehow 'special.' With a common border of more than $1,300 \mathrm{~km}$, Finland has always been closely tied to its eastern neighbour. Despite the physical proximity, the Cold War era closure of the border increased the mental distance between the two sides. For a long time, a good fence indeed made good neighbours, but it also made the other side seem increasingly unfamiliar. The resultant 'us' versus 'them' mentality sketched in the minds of many has proven to be far more deeply rooted and harder to erase than the border per se.

The Finnish nation building process in the late nineteenth century and particularly the post-Civil War White history writing have projected Russia as eternal other to Finland. In order to build a coherent nation, it was necessary to define who 'us' actually were and what was actually 'ours' - and in order to demarcate that, a border was utterly needed. In a way, the Finnish identity was built on differences vis-à-vis its neighbours; Finns were something that Swedes and Russian were not. Accordingly, the borders have played a key role in the Finnish nation and identity building; to remove them would therefore remove part of the Finnish identity.

Balancing at the border of East and West was not taken as a zero-sum game. Finnish President Paasikivi's dictum that if one bows to the West one is bound to turn one's bottom to the East - and vice versa - has never been put to a test. The mutually understood fact that "We cannot do anything for geography, nor can you" has been, contrary to its original connotation, transformed to mean that the two countries now had a lot of potential to utilise the opportunities offered by geographical proximity (see Stubb 2008).

The overriding question of Finnish foreign policy, as Finland's long-serving President (19561981) Urho Kekkonen (1958) explained, is the relations with her Eastern neighbour "upon which our destiny rests" and the "future of our nation depends..." - "[t] his always has been the case and always will be." Kekkonen had co-opted many of his ideas from his predecessor, J. K. Paasikivi, whose thinking derived from Lord Macaulay's suggestion that the beginning of all wisdom lay in the recognition of facts. Paasikivi's famous foreign policy line maintained that Finnish foreign policy should never run counter to the Soviet Union and our Eastern neighbour must be convinced of our determination to prove this. The Finnish-Soviet relations in aggregate became later personified strongly by Kekkonen, who discussed important issues directly with the Soviet leadership often with little or no consultation with his own administration or the parliament (Saukkonen 2006).

The 'Paasikivi line,' ranking all other issues behind relations with the Soviet Union, was adhered to for decades. Outside the country, the line became dubbed 'Finlandisation,' a term coined in 1961 by German political scientist Richard Löwenthal. The pros and cons of this policy are still actively debated. A secret CIA Intelligence Report of August 1972, which was approved for release in May 2007, found that "the Finns have ingeniously maintained their independence, but a limited one indeed, heavily influenced by the USSR's proximate military might, a preconditioned prudence not to offend Moscow, and the existence of various Soviet capabilities to complicate Finland's domestic life" (Central Intelligence Agency 1972: 3). Whereas the right-wing commentators accuse the Finnish government of continuing the policy of Finlandisation, commentators more towards the left underline that such an approach was, and to a limited degree still is, necessary in order to cope 
and deal with a culturally and ideologically alien superpower without losing sovereignty. Finlandisation has remained a sensitive issue in Finnish public discourse to this day.

As a Grand Duchy under Russian rule, Finland had maintained a custom border with Russia. Russia had been clearly the most important trade partner for Finland for decades until the World War I changed the situation profoundly. With the outbreak of war in 1914, Finland's foreign trade grew as a result of increased orders from Russia. At the same time, the trade deficit deepened due to the foreclosure of Western markets. A couple of years later, the situation changed even more drastically as a result of the Russian revolution and civil war in 1917; all forms of trade were terminated (Fig. 1). Russia's share of Finnish exports and imports fell abruptly from $97 \%$ and $68 \%$ respectively to zero (Finnish Customs 2007). The trade between the countries remained at very low levels throughout the entire 1920s and 1930s.

After the Second World War, trade upticked again, even though otherwise the border remained practically closed, as Finland was forced to pay the Soviet Union's sizeable war reparations. From the 1950s onwards, Finnish-Soviet trade was based on a bilateral clearing agreement, which dictated that both Finnish imports to and exports from the USSR had to be equal in value. This meant that the more
Finland purchased supplies from the USSR, the more the USSR was obligated to purchase supplies from Finland. This system was often presented, particularly in Soviet propaganda, as an example of how a large socialist country and a small capitalist country can engage in mutually beneficial cooperation and trade (Laurila 1995: 11).

Despite the strained relations during the postWorld War II climate, the Soviet Union was, until its collapse, by far Finland's most important trading partner. Even though largely politically determined, the bilateral trade had helped Finland to industrialise and contributed to its welfare in several ways. The Finnish economy had been structurally dependent on this trade with its Eastern neighbour to such an extent that its sudden disappearance contributed to an economic recession in Finland, which soon deepened into a depression on a scale not seen since the early 1930 s.

Trade relations have been on the mend from the 1998 Russian financial crisis. Even though trade and investments have not boomed hand in hand with levels of cross-border traffic, during the last decade trade between the countries grew steadily. A major driver behind the growth of Finnish exports to Russia was re-exports, i.e., goods that are imported by a purchaser in one country who then exports the product to a third country without processing (Ollus \& Simola 2007). The most recent

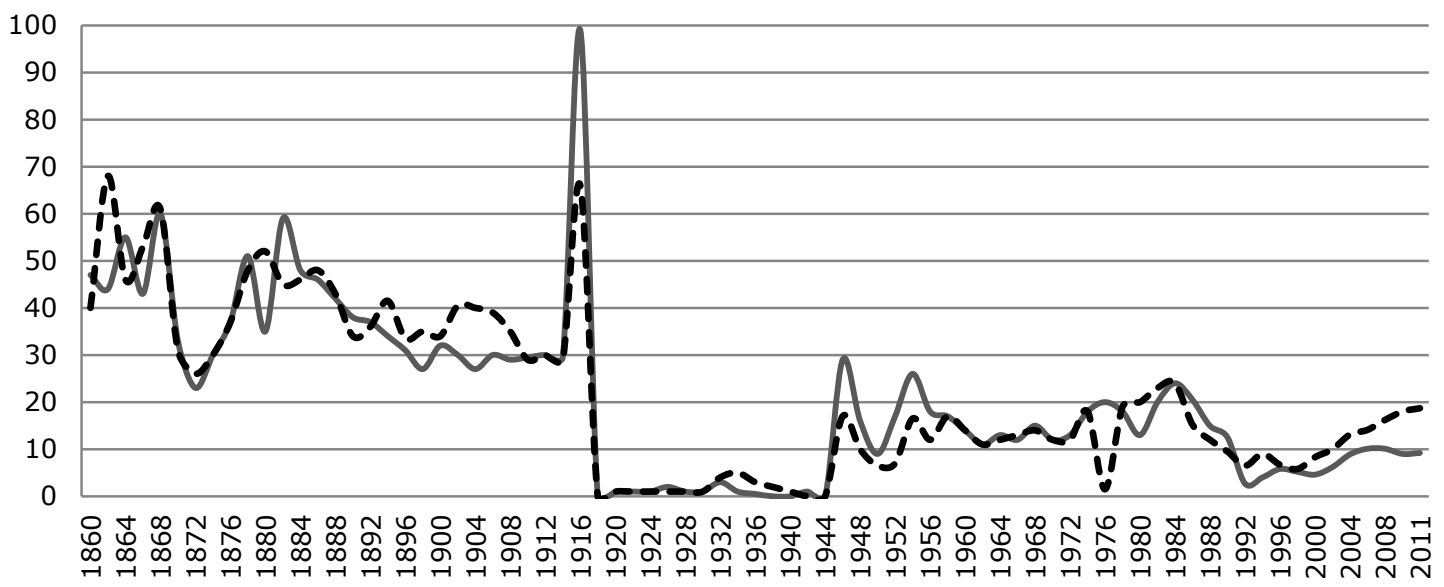

Exports to USSR/Russia

- - Imports to USSR/Russia

Fig. 1. Share of Russia/Soviet Union/Russia in Finland's Foreign Trade 1860-2011. Per cent of total exports and imports. Data Source: Bank of Finland and the National Board of Customs, Finland. 
economic crisis slowed down exports to Russia by not less than $47 \%$ and imports by $31 \%$ respectively between 2008 and 2009 (Finnish National Board of Customs 2009), thought already in 2011 imports ( $85 \%$ of which was energy) rebounded over the pre-crisis figures to more than EUR 11 billion and exports more modestly from EUR 4 billion in 2009 to EUR 5.3 billion in 2011 (Finnish National Board of Customs 2012).

As Haukkala (2003, 2009) argues, Finland has gained Russian elite's trust due to its historically rooted tendency towards pragmatism. He points out that unlike many central and eastern European countries traumatised by communist-era experiences of direct coercion and ideological subjectification, Finland's relationship with Russia has always been based on more or less voluntary and down-to-earth interaction. The continuation of this 'special relationship' does not imply that problems do not exist. Recent bilateral issues include, but are not limited to, persistent truck queues at the border, airspace violations, the pollution of the Baltic Sea, and an increase in Russian duties on wood exported to feed Finland's pulp and paper industry, the latter of which has, however, now been somewhat eased as the WTO welcomed the Russian Federation as its 156th member on August 22, 2012. The so-called Karelian question, the debate over Finland's re-acquisition of the ceded territories, and potential borderline adjustment pops up in the public discussion every now and then but cannot be regarded as a political issue as both of the governments in question agree that no open territorial dispute exists between the countries.

On the other hand, Russia has retained its position as Finland's favourite enemy. As stated by the former Minister of Defence Jyri Häkämies (National Coalition Party) in his (in-)famous speech given at the Center for Strategic and International Studies in Washington on September 6, 2007, the three main security challenges for Finland are "Russia, Russia, and Russia." It is unclear whether the uproar that followed was sparked by Häkämies being simply wrong or perhaps because his remarks had hit too close to the mark.

As the Cold War came to end along with the Soviet Union, academic research devoted to the topic of Russia was downscaled in most Western countries. In Finland, however, the opposite happened. A freer climate allowed for more objective research. Even so, most studies have focused on what Russia lacks rather than on what it has to offer. Few studies explore Russia as it was, but in- stead approach it as being always undergoing some kind of reform or transition into something (Smith 2012). As a result, the knowledge and understanding of the current situation in Russia as well as the factors behind it remained slim. This, in turn, limited the ability to realistically assess the impact of Russia on Finland and the rest of Europe as well as the extent to which there could be a meaningful debate about what should be done and, in particular, what can be done.

While what was stated above has sought to explain the broader context within which cross-border interaction has evolved, more attention needs to be paid on civil society and individuals' personal networks, which form the very backbone of the relations. While Finnish businesses have had clear difficulties adapting to the unfamiliar conditions in Russia and the jurisdiction of governments stops at the political border, individual citizens and civil society organisations are less restricted from moving back and forth across the border and entering into cooperative relationships. These connections also provide an alternative avenue for cooperation when interstate relations go sour and eventually play also a vital role in re-establishing relations.

The core of the cooperation is heavily based on very few key network actors. A lot of local level work has been and is done, which does not become visible through the analysis of different programs or funding instruments. Even if cooperation across the border has been troublesome and even disappointing for many individual actors and organisations, the networks have managed to keep up active cooperation across the border already for a long time - heedless of individual project time frames or funding periods. It is exactly this type of long-term cooperation that is perceived as most beneficial by the actors themselves.

\section{The Finnish-Russian relations and the border in between}

Finnish-Russian relations are a broader phenomenon than customary bilateral relations between two states. They are based on common history and those lessons learned from it, geographical proximity and the long common border, cultural linkages and the existence of kindred peoples, and economic development and trade interdependencies, as well as environmental factors that 
respect no borders. The relations have been both close and distant - at times both at the same time. They cannot be explained by the mere supply and demand factors, but the motivations for cooperation range from a sense of duty to an outright necessity. As a partner in cooperation, Russia is perceived at the same time as an opportunity and a drag, with high hopes and frustration. Like border regions in general, the Finnish-Russian border region is characterised by specific forms of living together that entail tolerance, solidarity and special know-how.

Only by being aware of the fact that the 'teachings of history' are open to various interpretations can the right decisions be made today without being blind to the political use of history. What Russia signifies to Finns has to be viewed through multiple lenses, all of which alter the picture in their own specific way. The era of Finland as an autonomous Grand Duchy in the Russian Empire, the nation building process in the latter half of the nineteenth century, years of oppression in the early 1900s, the confrontation between the bourgeois and the socialists, gaining independence in 1917, the civil war of 1918, the power struggle between democracy and the right-wing dictatorship from the 1920s until 1936, then the Winter and Continuation War, after which Finland had to live in the shadows of the Soviet Union for five decades, have all added something to the complexity of these bilateral relations.

Even though the Finnish-Soviet/Russian relations have been full of twists and turns, public opinion has changed more slowly. The analysis of this level of the relations is also important, as this is where much of the people-to-people interaction takes place. While more general Western attitudes towards Russia have turned, at times in an instant, from euphoria to outrage and from despair to hope, Finns' underlying attitudes towards Russia have been more stable. This can partly be explained by the fact that Russia is constantly present in the Finnish media and general public debate while elsewhere, further away, its image is formed based on more pointed events. Finns remain reserved and ground their stance on past experience. Whether this is called Russophobia or just realism depends on the angle taken.

The Finnish debate about Russia has certainly evolved during the last two decades, but the process has not been linear, nor has it been uncomplicated. Instead, multiple alternative trends have emerged and there is still plenty of room for inter- pretation. This is to say that the image and meaning of Russia has not simply changed from one to another, but it is seen differently in different contexts, at different levels sectors, and by different actors. Russia looks very different depending on whether it is approached at the level of everyday life, as a next-door neighbour, or as a global reemerging superpower.

The end of the Cold War provided a new beginning, but few knew exactly with whom Finland was now dealing with. The neighbour that Finns had learned to know, in both good and bad, suddenly disappeared. As a result, the previously stable border concept was also transformed into something broader and more complex. All this created uncertainly that downplayed the potential that could have been gained from the freer climate and the more open border. As a neighbour, the Soviet Union had not been the easiest kind, but at least the risk associated with living next to a sleeping giant could be assessed and managed, and the dangers could be judged. With its successor, the Russian Federation, the rules of the game changed fundamentally. The probabilities became harder to estimate because there was no longer any clear basis for making such a judgment.

Freer climate enabled new interpretations of the position of Finland, but they also marked deconstructive moments for the Finnish nation-state and the presumed unity between the nation and the state. Joenniemi (1993: 19) was quick to argue that as the permanent threat the Soviet Union was perceived to have lost its credibility, the meaning of state sovereignty could be put under scrutiny. The more open conditions allowed for the deconstruction of age-old stereotypes about 'Russianness' and 'Finnishness' derived from the past and related to World War II and the era of a closed border and also cleared the way for the image to be reconstructed in a more truthful manner.

EU membership provided further treatment for the long-common-border-syndrome and suggested a move away from the geodeterministic premise whereby the geography of Finland predetermined or at least limited its choices with regard to its political development. The increasingly international context necessitated that national unity be redefined once again. This process is evidently still going on today.

The external environment has changed radically during the last two decades and so too has Finland. Increased cooperation has eroded the understanding of the border with Russia as a 
strict cut-off line shutting-off contacts and retaining, if not generating, the mind-set of repression, injustice, conflict, or even war. While the border is still a state border, the transnational practices that transcend it allow it to be approached as a social practice, situated within an understanding of neighbourliness that recognises and respects the values of the other and the contributions that it makes. The opportunities that would be allowed by more open conditions have not, however, been grasped to their full potential. The mental aspects of the border remain etched into the minds of the people so profoundly that its relevance has not faded even though the actual institutional border has subsided. The border still functions as a barrier, but its partial permeability allows for the relations across it to be now, at last, shaped by dialog rather than by confrontation. This dialog allows both sides of the border to gain more knowledge about their neighbour, which in turn fosters mutual understanding, another important prerequisite for effective cooperation.

An unequal border setting, such as the Finnish-Russia border, is characterized not only by various asymmetries but also complementarities that, in turn, generate a variety of cross-border linkages. Increased linkages are not only a result of successful policies and practices, but also an essential prerequisite for future development. Thanks to the changes in the governance modes, rescaling of the state, constantly widening and deepening integration processes, strengthening regionalisation, and the raising influence of trans- and international organisations, the state is no longer the primary actor, nor is the nationstate the only conception of space to be applied in explaining human interaction. The state is not, however, disappearing but merely being organized differently. State sovereignty and authority has been weakened upwards, downwards, and sideways. There are increased negotiations not just among governments at several territorial tiers but also between the various sectors of society. The world politics of today involve many nonstate actors who interact with each other, with states, and with international organizations, at times skipping a level or two in between. When taken together, these revolutionary changes have led to a transition from international (border confirming) to transnational (border eroding) relations, implying, as a result, a clear shift away from state-centeredness.

\section{Concluding remarks: away from state centricity}

Borders are not fixed or something that must be overcome. They are evolving constructions, which have both merits and problems that must be constantly reweighed. This must be done, as Paasi has repeatedly argued, because borders are institutions and symbols that are produced and reproduced in social practices and discourses. As they can be constructed, they can also be deconstructed - should there be will to do so. As a band of border scholars have discovered, borders do not pre-exist, but they are always an outcome of social and political processes; change the process and you change the border.

Changing the focus from seeing like a state to seeing like a border, as Rumford (2008) has advised, would allow us to disaggregate the state and the border, and unveil the potential that various actors of civil society hold in constructing, shifting, or even in erasing borders. If the border is no longer seen in national terms, and if the interaction is deemed not to occur between two states, but among people from these two, or more, states, such borderwork would go beyond issues of national belonging or citizenship as to allow expressions of transnational mobility and sincere actorhood apart from state, or the EU, supported agendas. Various organisation of civil society are not only carrying out tasks defined by others. Instead, they themselves play a key role in articulating and modifying the objectives and practices of cooperation.

While the significance of the interstate relations and great power politics cannot be ignored, they alone are incapable of explaining the multileveled and multiscaled processes that take place today. Thanks to the institutionalisation of cooperation (e.g., Euregio Karelia), the relationships especially between regional level officials and authorities on the two sides of the border have improved. CBC projects and also less-visible personal-level interactions have significantly contributed to a more mutual understanding and interdependence, accumulation of trust, and the breaking down of mental barriers (cf. Németh et al. 2012). The relationship may still be far from ideal, or even what could be considered as normal between two countries 
sharing a long common border. Still, at least in comparison with high-level geopolitics, more bottom-up civil society cooperation seems to be developing forward and cultivating varying degrees of interdependence.

The ENP era brought along a greater emphasis on civil society in CBC across the external EU border but it also included a hidden agenda: an attempt to approach Russia through an alternative channel and to create operational basis for bottom-up forces seeking to influence the system. However, the post-Lisbon securitisation emphasis along the general new 'realism' in EU foreign policy has changed the picture yet again. Talks about the 'ring of friends,' which underlined the need to create better links with neighbours, now focus increasingly on a 'secure neighbourhood' and the need to create a supportive buffer zone. Accordingly, the EU seems to have lost some of its faith in CBC and in the transformation process in Russia. This has urged the Union to retreat precisely to where it should not be - at the level of socio-cultural communication.

If the local and regional level CBC is expected to thrive also in the future, all the levels will need to have better understanding of their own role and of the division of labour in this equation. More funding that is better directed, more easily accessible, and more reliable is needed where the practical knowledge and expertise is. It cannot be based on the superficial friendship rhetoric, but careful planning is needed in order to move beyond the formalities and maintain the cooperation successfully. Much depends on individual actors who are able to shoulder the implementation of the agreed programs and to solve emerging problems and disagreements.

As the EU's conditionality principle cannot be applied to Russia, a country without aspirations of EU membership, the carrot needs to be found elsewhere. Certainly, the EU's role in fuelling cooperation cannot be denied, as it certainly has created a supportive frame and a forum within which cooperation and regional dialogue has developed. It has also brought new impetus and forced the Finnish actors to move beyond the old rhetoric based on past experiences. Still, the future trajectory whereby binational cooperation would rely entirely on support from Brussels sounds very unnatural. Especially as long as there are no practical means to distribute EU funds to the local level where much of the work is carried out. The main motives and initiatives for the cooperation have to arise from the local needs and concerns.

In the light of current trends towards the decentralisation and privatisation of public services in both Finland and Russia, it would be prescient to conceptualise a cross-border space for social contracting and social welfare policies through civil society organisations. Such a more social economy focused approach would offer alternative ways to generate social and economic welfare and innovative solutions to society's most pressing social problems thought social entrepreneurship. New support structures could promote collaborative forms of policy formulation and delivery based on partnerships involving the state, the private sector, foundations, and civil society at large. This is particularly important in peripheral regions with limited prospects for short-term returns on social investment and where multiple support mechanisms are needed in order to nurture entrepreneurial activity. One possible strategy would be to develop international networks between public, private, and nonprofit sector actors that provide assistance to emerging and future social entrepreneurs through a variety of means, including: support in project development, securing grants, and assistance in the acquisition and provision of loans and investment capital, as well as training, advisory, logistical, and informational support.

The best way to normalise neighbourly relations is through increased people-to-people interaction, and preferable this ought to occur from the bottom-up, not from the top-down. Given that the NAC program has been terminated and that the ENPI CBC is not properly equipped to deal with the overall context within which Finnish-Russian cooperation takes place, there is a risk that despite the rhetorical statements suggesting otherwise, the EUropeanisation of Finnish-Russian cooperation may well become underfunded and more technocratic. This will put the durability of cross-border contacts to the test, but it also allows $\mathrm{CBC}$ to be restructured and redesigned away from predefined funding programs, periods, and priorities. Unrestricted people-topeople interaction feeds inspiration and innovation and leads to new solutions - also in terms of financing. There is little reason to expect anything less. 


\section{REFERENCES}

Agnew J 2005. Hegemony: the new shape of global power. Temple University Press, Philadelphia.

Alapuro R 1988. State and revolution in Finland. University of California Press, Berkeley.

Alapuro R \& Stenius H 1989. Kansanliikkeet loivat kansakunnan. In Alapuro R, Liikanen I, Smeds, K \& Stenius H (eds). Kansa liikkeessä, 8-49. Kirjayhtymä, Vaasa.

Amoore L 2009. Lines of sight: on the visualization of unknown futures. Citizenship Studies 13: 1, 17-30. http://dx.doi.org/10.1080/13621020802586628.

Anderson J, O'Dowd L \& Wilson TM (eds) 2003. New borders for a changing Europe. Frank Cass, London.

Baerwald TJ 2010. Prospects for geography as an interdisciplinary discipline. Annals of the Association of American Geographers 100: 3, 493-501. http:// dx.doi.org/10.1080/00045608.2010.485443.

Balibar E 2009. Europe as borderland. Environment and Planning D: Society and Space 27: 2, 190-215. http://dx.doi.org/10.1068/d13008.

Brunet-Jailly E 2004. Toward a model of border studies: what do we learn from the study of the CanadianAmerican border? Journal of Borderlands Studies 19: 1, 1-12. http://dx.doi.org/10.1080/08865655.2004. 9695613.

Brunet-Jailly E 2005. Theorizing borders: an interdisciplinary perspective. Geopolitics 10: 4, 633-649. http:// dx.doi.org/10.1080/14650040500318449.

Central Intelligence Agency 1972. 'Finlandization' in action: Helsinki's experience with Moscow. RSS No. 0059/72.

Dimitrovova B 2012. Imperial re-bordering of Europe: the case of the European Neighbourhood Policy. Cambridge Review of International Affairs 25: 2, 249-267. http://dx.doi.org/10.1080/09557571.201 2.678298 .

Elden S 2009. Terror and territory: the spatial extent of sovereignty. University of Minnesota Press, Minneapolis.

Emerson M 2001. The elephant and the bear: the European Union, Russia and their near abroad. Centre for European Policy Studies, Brussels.

Finnish Customs 2007. <www.tullifi/en/finnish_customs/statistics/> 7.10.2008.

Finnish National Board of Customs 2009. <www.tulli.fi/ en/finnish_customs/statistics/statistics/country/> 7.12.2012.

Finnish National Board of Customs 2012. <www.tulli.fi/ fi/tiedotteet/ulkomaankauppatilastot/katsaukset/ maat/venaja12/index.html>11.12.2012.

Githens-Mazer J 2007. Ethno-symbolism and the everyday resonance of myths, memories and symbols of the nation. Paper presented at conference on Everyday Life in World Politics and Economics, 11 May 2007, Centre for International Studies, LSE, London.

Haukkala H 2003. A problematic 'strategic partnership'. In Lynch D (ed). EU-Russia security dimensions, 8-19. European Union Institute for Security Studies, Paris.
Haukkala H 2009. Lost in Translation? Why the EU has failed to influence Russia's development. EuropeAsia Studies 61: 10, 1757-1775.

http://dx.doi.org/10.1080/09668130903278942.

Houtum van $\mathrm{H}$ \& Boedeltje F 2009. Europe's shame: death at the borders of the EU. Antipode 41: 2, 226230 .

http://dx.doi.org/10.1111/j.1467-8330.2009.00670.x.

Houtum van $\mathrm{H}$ \& Naerssen van T 2002. Bordering, ordering and othering. Tijdschrift voor Economische en Sociale Geografie 93: 2, 125-136. http://dx.doi. org/10.1111/1467-9663.00189.

Houtum van H \& Pijpers R 2007. The European Union as a gated community of fear: the two-faced border and immigration regime of the EU. Antipode 39: 2, 291-309.

http://dx.doi.org/10.1111/j.1467-8330.2007.00522.x.

Joenniemi P 1993. Euro-Suomi: rajalla, rajojen välissä vai rajaton? In Joenniemi P, Alapuro R \& Pekonen K (eds). Suomesta Euro-Suomeen: Keitä me olemme ja mihin matkalla, 17-48. Tampere Peace Research Institute, Tampere.

Johnson CM 2009. Cross-border regions and territorial restructuring in Central Europe: room for more transboundary space. European Urban and Regional Studies 16: 2, 177-191. http://dx.doi.org/10.1177/0969776409102190.

Katajala K 1999. Near the metropolis, beyond the border: St Petersburg and Eastern Finland before the October Revolution. In Eskelinen H, Liikanen I \& Oksa J (eds). Curtains of iron and gold: reconstructing borders and scales of integration, 297-315. Ashgate, Aldershot.

Kekkonen U 1958. The beginning of cool relations. Broadcast on 10 December 1958, in Helsinki. <http://www.doria.fi/bitstream/handle/10024/10375/TMP.objres. 1451. html?sequence=1>14.12.2012.

Kolossov V 2005. Border studies: changing perspectives and theoretical approaches. Geopolitics 10: 4, 1-27. http://dx.doi.org/10.1080/14650040500318415.

Laine J 2011. In search of balance: Russia and the EU in the North. Polar Geography 34: 3, 163-192. http:// dx.doi.org/10.1080/1088937X.2011.597886.

Laine J 2013. New civic neighborhood: cross-border cooperation and civil society engagement at the Finnish-Russian border. Publications of the University of Eastern Finland. Dissertations in Social Sciences and Business Studies, no 58.

Laurila J 1995. Finnish-Soviet clearing trade and payment system: history and lessons. Bank of Finland, Helsinki.

Liikanen I 1995. Fennomania ja kansa: joukkojärjestäytymisen läpimurto ja suomalaisen puolueen synty. Finnish Historical Society, Helsinki.

Liikanen I, Zimin D, Ruusuvuori J \& Eskelinen H 2007. Karelia - a cross-border region? The EU and cross-border region-building on the Finnish-Russian border. University of Joensuu, Joensuu.

Lounasmeri L 2011. Lähellä, mutta niin kaukana? Suomalaisen Venäjäkuvan äärellä. In Lounasmeri L (ed). Näin 
naapurista: median ja kansalaisten Venäjä-kuvat, 7-15. Vastapaino, Tampere.

Moisio S 2003. Back to Baltoscandia? European Union and geo-conceptual remaking of the European North. Geopolitics 8: 1, 72-100. http://dx.doi.org/10.1080/714001004.

Moré I 2011. The borders of inequality: where wealth and poverty collide. University of Arizona Press, Tucson.

Németh S, Fritsch M, Eskelinen H, Izotov A, Scott JW \& Zimin D 2012. Case study on Finland-Russia. In TERCO European Territorial Cooperation as a Factor of Growth, Jobs and Quality of Life Final Report, 213-276. ESPON \& EUROREG - Centre for European Regional and Local Studies, University of Warsaw, Warsaw.

Newman D 2003a. Boundaries. In Agnew J, Mitchell K \& Toal G (eds). A Companion to Political Geography, 123-137. Blackwell, Oxford.

Newman D 2003b. On borders and power: a theoretical framework. Journal of Borderlands Studies 18: 1, 13-26. http://dx.doi.org/10.1080/08865655.2003.9695598.

Newman D 2006. The lines that continue to separate us: borders in our 'borderless' world. Progress in Human Geography 30: 2, 143-161. http://dx.doi.org/10.1191/0309132506ph599xx.

Newman D 2012. Where to in border studies? Crossing the disciplinary borders in the search for questions. Paper presented at the Borderscapes III Conference, 28 June 2012, Trieste.

O'Dowd L 2010. From a 'borderless world' to a 'world of borders': 'bringing history back in'. Environment and Planning D: Society and Space 28: 6, 1031-1050. http://dx.doi.org/10.1068/d2009.

Ollus S-E \& Simola H 2007. Finnish re-exports to Russia. BOFIT Online 5.

Paasi A 1996. Territories, boundaries and consciousness: the changing geographies of the Finnish-Russian border. John Wiley \& Sons, Chichester.

Paasi A 1999. Boundaries as social practice and discourse: the Finnish-Russian border. Regional Studies 33: 7, 669-680. http://dx.doi.org/10.1080/00343409950078701.

Paasi A 2005a. The changing discourses on political boundaries: mapping the backgrounds, contexts and contents. In Houtum van $\mathrm{H}$, Kramsch O \& Zierhofer W (eds). B/ordering the world, 17-31. Ashgate, Aldershot.

Paasi A 2005b. Generations and the development of border studies. Geopolitics 10: 4, 663-671. http://dx.doi. org/10.1080/14650040500318563.

Paasi A 2009. Bounded spaces in a 'borderless world': border studies, power and the anatomy of territory. Journal of Power 2: 2, 213-234. http://dx.doi.org/10.1080/17540290903064275.

Payan T 2013. Theory-building in border studies: the View from North America. Eurasia Border Review 5: 1, 1-18.
Popescu G 2008. The conflicting logics of cross-border reterritorialization: geopolitics of euroregions in Eastern Europe. Political Geography 7: 4, 418-438. http://dx.doi.org/10.1016/j.polgeo.2008.03.002.

Rosière S \& Jones R 2012. Teichopolitics: reconsidering globalization through the role of walls and fences. Geopolitics 17: 1, 217-234. http://dx.doi. org/10.1080/14650045.2011.57465.

Rovisco M 2010. Reframing Europe and the global: conceptualizing the border in cultural encounters. Environment \& Planning D: Society \& Space 28: 6, 1015-1030. http://dx.doi.org/10.1068/d0809.

Rumford C 2006. Theorizing borders. European Journal of Social Theory 9: 2, 155-169. http://dx.doi. org/10.1177/1368431006063330.

Rumford C 2008. Citizens and borderwork in contemporary Europe. Routledge, London.

Rumyantsev A 2012. <www.rusembassy.fi/OpenFiles/01.09.2012.pdf>12.10.2012.

Saukkonen P 2006. <blogs.helsinki.fi/vol-spj> 29.8.2012.

Scott JW \& Houtum van H 2009. Reflections on EU territoriality and the 'bordering' of Europe. Political Geography 28: 5, 271-273. http://dx.doi. org/10.1016/j.polgeo.2009.04.002.

Scott JW 2009. Bordering and ordering the European Neighbourhood: a critical perspective on EU territoriality and geopolitics. Trames 13: 3, 232-247. http://dx.doi.org/10.3176/tr.2009.3.03.

Sidaway JD 2001. Rebuilding bridges: a critical geopolitics of Iberian transfrontier cooperation in a European context. Environment and Planning D: Society and Space 19: 6, 743-778. http://dx.doi. org/10.1068/d223t.

Smith J 2012. The problem of succession in Russia, 1019-2012. Paper presented during the VERA Day, 4 May 2012, Joensuu, Finland.

Strober MH 2006. Habits of the mind: challenges for multidisciplinary engagement. Social Epistemology 20: 3-4, 315-331. http://dx.doi.org/10.1080/02691720600847324.

Stubb A 2008. Venäjään on suhtauduttava ilman komplekseja siitä, mitä Neuvostoliitto joskus aikoinaan on ollut. Savon Sanomat 23.4.2008.

Stubb A 2009. Foreword: Northern Dimension. Publications of the Ministry for Foreign Affairs of Finland. Ministry for Foreign Affairs of Finland, Helsinki.

Sutela P 2001. Finnish relations with Russia 19912001: better than ever? Paper presented at the Norwegian Institute for Defence Studies conference on "Living Next Door to Russia - the First Ten Years seen From the Neighbours' Perspective" (BOFIT Online 11/2001), 11 October 2001, Oslo.

Warkentin C 2001. Reshaping world politics: NGOs, the internet, and global civil society. Rowman Littlefied Publishers, Lanham. I 